\title{
Almihjam Expert System Menggunakan Logika Fuzzy Fordward Chaining Untuk Penentuan Titik Bekam Basah
}

\author{
Ita Fitriati ${ }^{1}$, Muhammad Ghazali ${ }^{2, *}$ \\ ${ }^{1,2}$ STKIP Taman Siswa Bima \\ ${ }^{1}$ itafitriati88@gmail.com, ${ }^{2}$ m.ghazali11@gmail.com \\ ${ }^{*}$ Corresponding Author
}

\section{Artikel Info}

Tanggal Publikasi

2019-06-30

Kata Kunci

Almihjam Expert

System

Fordward Chaining Fuzzy

\begin{abstract}
Abstrak
Bekam basah menjadi salah satu metode penyembuhan alternatif yang kini banyak diminati oleh masyarakat. Klinik bekam sering dipenuhi oleh pasien karena merupakan pengobatan alternatif yang terjangkau. Biasanya sebelum melakukan proses bekam, terapis melakukan konsultasi kepada pasien sebelum memberikan tindakan, namun terkadang juga dari terapis langsung melakukan pembekaman tanpa memberikan informasi kepada pasien. Peneliti menawarkan sebuah expert system yang bisa dimanfaatkan oleh terapis sekaligus pasien, sehingga diharapkan adanya keterbukaan informasi antara keduanya. Terapis memanfaatkan aplikasi ini untuk mempercepat pengambilan keputusan tindakan penyembuhan, sedangkan pasien bisa mendapatkan informasi detail terkait penyakit yang diderita. Diberi nama Almihjam Expert System yang menggabungkan metode Forward Chaining dan Metode Fuzzy. Metode Forward Chaining digunakan untuk menentukan rule berdasarkan gejala keluhan yang dialami pasien, sedangkan metode Fuzzy digunakan karena kemampuan fuzzy yang memiliki nilai toleransi yang mampu memetakan probabilitas yang kompleks. Penelitian ini bertujuan: (1) Menghasilkan sebuah sistem yang menampilkan informasi bekam yang lengkap untuk pasien, (2) Menghasilkan sistem yang dimanfaatkan oleh terapis untuk pengambilan keputusan terhadap hasil pemeriksaan pasien. Pada saat uji coba sistem yang dilakukan terhadap dua orang asisten pakar terlihat nilai respon 76,7\% dengan kategori Baik. Hasil implementasi sistem yang dilakukan pada 15 orang pasien menunjukan nilai rerata $81,5 \%$ dengan kategori Sangat Baik.
\end{abstract}

\section{PENDAHULUAN}

Banyak metode penyembuhan alternatif yang kini menjadi pilihan bagi para pasien yang menginginkan kesembuhan dari berbagai macam penyakit yang diderita, baik itu penyakit ringan dengan kasus non-operasi maupun penyakit berat yang meliputi organ-organ dalam tubuh atau biasa disebut penyakit dalam (Interna).Salah satu metode tersebut diantaranya adalah Metode Alhijamah atau biasa disebut terapi bekam. Bekam merupakan proses mengeluarkan darah dari kulit dengan cara menghisap, kemudian menyayat ringan pada permukaan kulit, kemudian dilakukan penghisapan lagi agar darah bisa keluar dan menimbulkan kesembuhan dengan izin Allah (Umar, 2016).

Bekam basah menjadi salah satu metode penyembuhan alternatif yang banyak diminati oleh masyarakat di Bima Nusa Tenggara Barat, kebanyakan di klinik bekam selalu dipenuhi oleh banyak pasien, baik laki-laki maupun perempuan, dewasa maupun lansia. Berdasarkan observasi awal yang dilakukan bulan Juni 2018 di klinik CTC (Cupping Teraphy Center) Kota Bima dengan mewawancarai pemilik klinik yaitu bapak Irwan,S.Pd.I.,CHT, didapatkan informasi bahwa pasien sangat banyak datang ke kliniknya, masyarakat lebih meyakini metode bekam lebih baik dari pada mengkonsumsi obat-obatan yang belum ada jaminan kehalalannya. Selain itu menurut salah satu terapis lainnya mengatakan seiring dengan banyaknya jenis penyakit baru yang bermunculan serta dengan keluhan yang berbeda-beda yang mengakibatkan selalu terjadinya keterlambatan dalam 
pengambilan keputusan dalam menentukan urutan pengobatan untuk pasien, dan juga penentuan titik bekam yang akan diberikan untuk pasien.

Informasi bersumber dari salah satu pasien, bahwa pasien menginginkan adalnya informasi detail yang bisa didapatkan terkait penyakit yang diderita maupun solusi untuk penyembuhan secara metode bekam.

Dengan adanya permasalahan diatas sehingga peneliti menganggap perlu untuk merancang sebuah Sistem Expert yang mampu memberikan jawaban cepat atas segala keluhan pasien beserta terapis.

Sistem ini akan dibuat dengan strategi forward chaining digunakan pada pengujian fakta-fakta yang dimasukkan oleh pakar terapis, dengan aturan yang telah disimpan dalam sistem, sehingga menghasilkan satu kesimpulan berupa titik bekam

Tujuan dari penelitian ini adalah: (1) Menghasilkan sebuah sistem yang menampilkan informasi bekam yang lengkap untuk pasien. (2) Menghasilkan sistem yang dimanfaatkan oleh terapis untuk pengambilan keputusan terhadap hasil pemeriksaan pasien. (3) Menampilkan informasi titik bekam dari hasil pemanfaatan forward chaining dan metode Fuzzy.

\section{Bekam Basah}

Berbagai macam metode penyembuhan alternatif saat ini menjadi pilihan bagi para pasien yang menginginkan kesembuhan bagi berbagai macam penyakit yang diderita, baik itu penyakit ringan dengan pengobatan tanpa operasi maupun penyakit berat yang meliputi organ-organ dalam tubuh. Beberapa metode alternatif itu diantaranya adalah pengobatan islami yaitu Bekam atau AlHijamah adalah proses mengeluarkan darah kotor yang tidak diperlukan oleh tubuh yang bertujuan untuk mencegah timbulnya berbagai macam penyakit.

Metode pengobatan bekam basah adalah dengan menggunakan tabung, cawan, tanduk hewan atau bambu yang prosesnya dimulai dengan membuat tekanan menjadi negatif dalam wadah cawan sehingga melakukan pengisapan atau vakumisasi. Sehingga darah kotor tertarik mendekati kulit titik bekam yang dikeluarkan dengan menyayat tipis di kulit pada titik-titik bekam.

Secara garis besar fungsi bekam diantaranya adalah untuk mengeluarkan darah kotor atau darah yang berpotensi mengandung toksin. Dengan dikeluarkannya toksin dan sel darah yang rusak atau tidak bagus kinerjanya maka tubuh menjadi lebih bugas dan sehat. Selain itu fungsi berikutnya adalah perbaikan fungsi organ tubuh. Organ tubuh yang terganggu fungsinya dapat disembuhkan dengan cara perbaikan jaringan dan sel yang ada padanya sehingga bisa berfungsi dan sehat kembali. Organ tubuh yang terinfeksi kuman penyakit dapat sembuh secara alami karena tubuh memproduksi zat antibodi yang bisa membunuh kuman penyakit yang merugikan. Jika organ tubuh sudah bebas dari infeksi penyakit maka tubuh pun kembali sehat.

Bagi penderita hipertensi, bekam berperan mengurangi kadar lemak dan kolesterol berbahaya (LDL) dalam darah maupun yang mengendap di dinding pembuluh darah sehingga mengurangi penyumbatan pembuluh darah. Bekam juga meningkatkan suplai darah ke lapisan dalam endothelium yang berperan memproduksi zat nitrit oksida (endothelium-derived relaxing factor) yang membantu peregangan dan pelebaran dinding pembuluh darah (Akbar \& Mahati, 2013).

Selama ini tindakan yang diberikan kepada pasien hanya berdasar pada perkiraan praktisi pengobatan untuk menarik kesimpulan atas semua kemungkinan penyakit yang diderita oleh pasien. Semakin banyak gejala yang ditimbulkan maka semakin banyak pula muncul prediksi-prediksi penyakit. Karena banyaknya prediksi pernyakit yang berbeda-beda maka akan semakin banyak pula solusi penyembuhan yang dilakukan. Karena itu dibutuhkan Expert System yang membantu praktisi 
pengobatan. Expert Systemyang digunakan pada penelitian ini memadukan metode Fuzzy dengan Forward Chaining.

\section{Logika Fuzzy}

Logika Fuzzy adalah suatu cabang ilmu Artificial Intellegence, yaitu suatu pengetahuan yang membuat komputer bisa meniru kecerdasan manusia sehingga diharapkan komputer dapat melakukan hal-hal yang apabila dikerjakan manusia memerlukan kecerdasan (Adrial, 2017)(Fitriati \& Ghazali, 2018). Logika Fuzzy merupakan metode pemecahan masalah yang digunakan pada sistem, jaringan, sistem kontrol. Berbeda dengan Logika klasik yang hanya memiliki dua kemungkinan (biner) yang terdiri dari benar atau salah, dengan fungsi nilai keanggotaan hanya 0 dan 1, sedangkan Logika Fuzzy memungkinkan fungsi nilai keanggotan berkisar antara 0 sampai 1. Logika Fuzzy memungkinkan keadaan berada dalam dua keanggotaan sekaligus tergantung bobot nilai keanggotaannya (Sutojo, Mulyanto, \& Suhartono, 2011).

Kelebihan Logika Fuzzy adalah memiliki toleransi terhadap data yang tidak tepat sehingga lebih mampu memodelkan persamaan nonlinear yang kompleks. Sehingga penalarannya tidak membutuhkan persamaan matematika yang rumit (Fitriati, 2015).

Dibutuhkan suatu certainty factor (CF) yang menyatakan tingkat keyakinan pakar dalam suatu pertanyaan. CF ini bernilai antara rentang 0 (tidak pasti) sampai 1 (pasti). Nilai CF terbagi menjadi unknown / tidak pasti (0-0.2), maybe / mungkin (0.4), probably/ kemungkinan besar (0.6), almost certainly/ hampir pasti (0.8) dan definitely/ pasti (1.0). Nilai CF ini diperoleh dari hasil mewawancarai praktisi kesehatan. Peneliti memberikan suatu nilai kondisi kemudian pakar menentukan penilaian bobot tiap tipe gejala yang berdasarkan pengalaman dari kondisi pasien yang telah ditangani sebelumnya.

\section{Forward Chaining}

Pada system pakar berbasis rule, domain pengetahuan direpresentasikan dalam sebuah kumpulan rule berbentuk IF-THEN, sedangkan data direpresentasikan dalam sebuah kumpulan fakta-fakta tentang kejadian saat ini. Mesin Inferensi membandingkan masing-masing rule yang tersimpan dalam basis pengetahuan dengan fakta-fakta yang terdapat dalam database. Jika bagian IF (kondisi) dari rule cocok dengan fakta, maka rule dieksekusi dan bagian THEN (aksi) diletakkan dalam database sebagai fakta baru yang ditambahkan (Hamdani, 2016).

Forward chaining adalah strategi penarikan kesimpulan yang dimulai dari sejumlah faktafakta yang telah diketahui, untuk mendapatkan suatu fakta baru dengan memakai rule-rule yang memiliki premis yang cocok dengan fakta dan terus dilanjutkan sampai mendapatkan tujuan atau sampai tidak ada rules yang punya premis yang cocok atau sampai mendapatkan fakta (Yunus \& Setyowibowo, 2011).

Forward chaining merupakan strategi pencarian yang memulai proses pencarian dari sekumpulan data atau fakta, dari data-data tersebut dicari suatu kesimpulan yang menjadi solusi dari permasalahan yang dihadapi. Mesin inferensi mencari kaidah-kaidah dalam basis pengetahuan yang premisnya sesuai dengan data-data tersebut, kemudian dari kaidah-kaidah tersebut diperoleh suatu kesimpulan. Forward chaining memulai proses pencarian dengan data sehingga strategi ini disebut juga data-driven (Hayadi \& Rukun, 2016).

\section{METODE PENELITIAN}

Jenis penelitian ini merupakan penelitian eksperimental yang bersifat aplikatif sehingga dari perumusan masalah dapat dilakukan dengan metode studi literatur (library research), metode pengumpulan data lapangan (field research) dan pembuatan aplikasi berbasis website berdasarkan 
analisis Forward Chaining Menggunakan Fuzzy. Adapun data yang digunakan dalam penelitian ini adalah: (1) Data Primer, yakni pengumpulan data melalui wawancara dengan para terapis dan dokter, mengambil data Certain Factor. (2) Data Sekunder, dilakukan dengan penelusuran kepustakaan dengan menggali dan mencari semua informasi yang didapat melalui buku, internet, dan penunjang lainnya.

\section{HASIL DAN PEMBAHASAN}

Sistem ini memadukan dua algoritma yaitu algoritma forward chaining dan algoritma fuzzy. Algoritma forward chaining berbasis rule, domain pengetahuan diimplementasikan dalam sebuah kumpulan rule berbentuk if-then, sedangkan data direpresentasikan dalam sebuah kumpulan faktafakta tentang kejadian saat ini. Mesin Inferensi membandingkan masing-masing rule yang tersimpan dalam basis pengetahuan dengan fakta-fakta yang terdapat dalam database. Jika bagian IF (kondisi) dari rule cocok dengan fakta, maka rule dieksekusi dan bagian THEN (aksi) diletakkan dalam database sebagai fakta baru yang ditambahkan.

Dalam logika klasik dinyatakan bahwa segala sesuatu bersifat biner, yang artinya adalah hanya mempunyai dua kemungkinan, "Ya atau Tidak", "Benar atau Salah", Baik atau Buruk", dan lain-lain. Oleh karena itu, semua ini dapat mempunyai nilai keanggotaan 0 dan 1 . Akan tetapi, dalam logika fuzzy memungkinkan nilai keanggotaan berada diatara 0 dan 1 . Artinya, bisa saja suatu keadaan mempunyai dua nilai "Ya dan Tidak" secara bersamaan, namun besar nilainya bergantung pada bobot keanggotaan yang dimilikinya

Perhitungan Certainty Factor pada sistem menggunakan pengukuran yang tidak pasti, dibutuhkan suatu certainty factor yang menyatakan tingkat keyakinan sang pakar dalam suatu pernyataan. CF dinilai dengan angka dalam rentang 0 (tidak pasti) sampai 1 (pasti). Tabel kondisi dan nilai CF dapat dilihat pada Tabel 1.

Tabel 1. Kondisi dan Nilai CF

\begin{tabular}{cc}
\hline Uncertain Term /Kondisi Tidak Pasti & CF \\
\hline Unknown / Tidak pasti & $0-0.2$ \\
Maybe / Kemungkinan & 0.4 \\
Probably / Kemungkinan besar & 0.6 \\
Almost certainly / Hampir pasti & 0.8 \\
Definitely / Pasti & 1.0 \\
\hline
\end{tabular}

Pada sistem nilai CF ini diperoleh dari pakar lewat isian angket yang diberikan oleh peneliti, peneliti memberikan suatu nilai kondisi keterkaitan antara gejala dan penyakit selanjutnya pakar yang akan menentukan nilai bobot pada tiap gejala yang telah diketahui. Pakar menentukannya berdasarkan pengalaman dari penyakit dan gejala pasien-pasiennya.

Keluhan pasien dapat ditampilkan dalam knowledge pada Tabel 2.

Tabel 2. Kode Gejala dan Penyakit

\begin{tabular}{llcl}
\hline Kode & Gejala & Kode & Penyakit \\
\hline G022 & Cepat Lelah & P01 & Amandel \\
\hline G030 & Gangguan penglihatan & P02 & Anemia \\
\hline G053 & Sulit tidur & P04 & Diabetes Militus \\
\hline G085 & Mual atau Muntah & P05 & Gangguan kandung Kemih \\
\hline G105 & Pusing & P06 & Gangguan Pankreas \\
\hline G109 & Sakit kepala akut & P07 & Ginjal \\
\hline
\end{tabular}




\begin{tabular}{lll}
\hline & P08 & Hipertensi \\
\hline P09 & Insomnia \\
\hline P13 & Masalah Jantung \\
\hline P14 & Migrain \\
\hline P15 & Obesitas \\
\hline P16 & Penyakit Mata \\
\hline P17 & Rematik \\
\hline P20 & Sirkulasi darah tidak lancar \\
\hline P21 & Stroke \\
\hline P23 & Alergi \\
\hline
\end{tabular}

Keterkaitan Gejala dan penyakit dapat ditampilkan dalam bentuk diagram dalam Gambar 1.

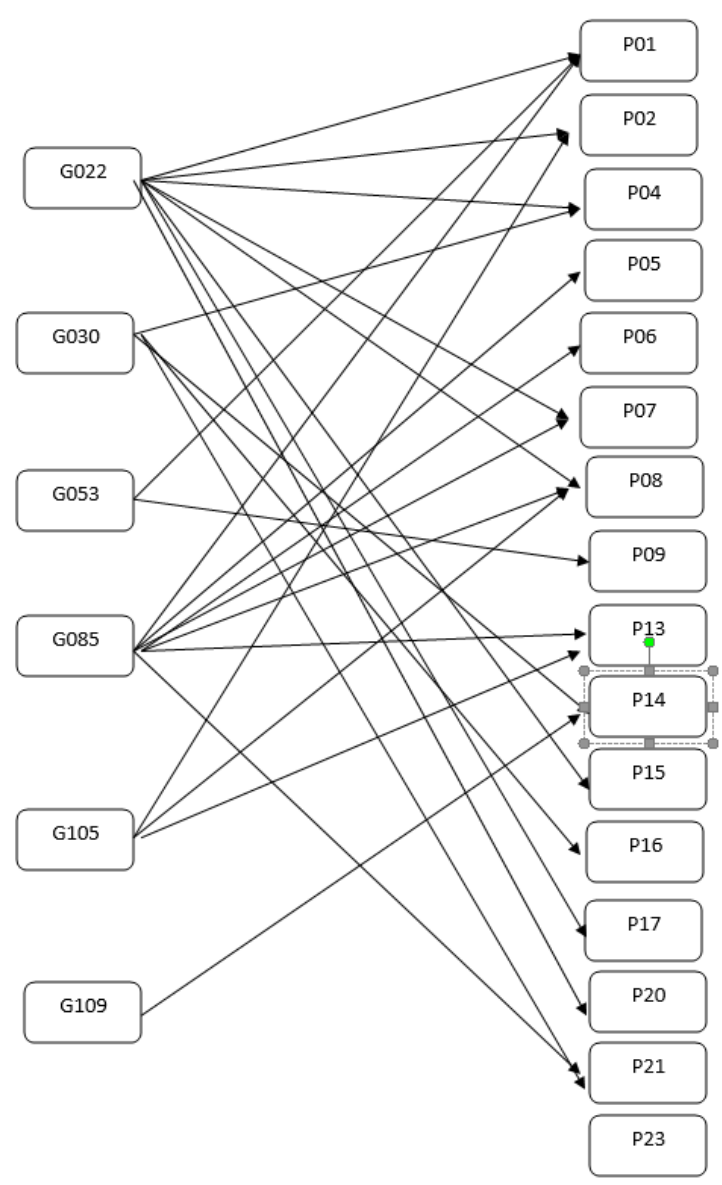

Gambar 1. Keterkaitan gejala dan penyakit.

Gejala dan penyakit tersebut dibawa ke mesin inference dengan total CF dan persentase seperti Tabel 3 berikut ini:

Tabel 3. CF dan persentase

\begin{tabular}{|c|c|c|c|c|c|c|}
\hline \multicolumn{3}{|c|}{ Kode Gejala } & Kode Penyakit & $\mathrm{CF}$ & Total CF & $\%$ \\
\hline If & G085 & Then & $\mathrm{P} 23$ & 0,4 & 0,8 & $4,70 \%$ \\
\hline If & G022 & Then & P01 & 0,4 & & \\
\hline If & G085 & Then & $\mathrm{P} 01$ & 0,4 & 1,8 & $10,50 \%$ \\
\hline If & G053 & Then & P01 & 0,6 & & \\
\hline If & G022 & Then & $\mathrm{P} 02$ & 0,6 & 14 & \\
\hline If & G105 & Then & $\mathrm{P} 02$ & 0,8 & 1,4 & $8,10 \%$ \\
\hline
\end{tabular}




\begin{tabular}{|c|c|c|c|c|c|c|}
\hline If & G022 & Then & P04 & 0,6 & \multirow{2}{*}{0,8} & \multirow{2}{*}{$4,70 \%$} \\
\hline If & G030 & Then & P04 & 0,6 & & \\
\hline If & G085 & Then & P05 & 0,4 & 0,4 & $2,30 \%$ \\
\hline If & G085 & Then & P06 & 0,4 & 0,6 & $3,50 \%$ \\
\hline If & G022 & Then & $\mathrm{P} 07$ & 0,8 & \multirow{2}{*}{1,2} & \multirow{2}{*}{$7,00 \%$} \\
\hline If & G085 & Then & $\mathrm{P} 07$ & 1 & & \\
\hline If & G022 & Then & P08 & 0,4 & \multirow{4}{*}{2,8} & \multirow{4}{*}{$16,30 \%$} \\
\hline If & G030 & Then & P08 & 0,4 & & \\
\hline If & G085 & Then & P08 & 0,8 & & \\
\hline If & G105 & Then & P08 & 0,6 & & \\
\hline If & G053 & Then & P09 & 0,4 & 1 & $5,80 \%$ \\
\hline If & G085 & Then & P13 & 0,6 & \multirow{2}{*}{0,8} & \multirow{2}{*}{$4,70 \%$} \\
\hline If & G105 & Then & P13 & 0,6 & & \\
\hline If & G030 & Then & P14 & 0,8 & \multirow{2}{*}{1,8} & \multirow{2}{*}{$10,50 \%$} \\
\hline If & G109 & Then & P14 & 0,4 & & \\
\hline If & G022 & Then & P15 & 1 & 0,8 & $4,70 \%$ \\
\hline If & G030 & Then & P16 & 1 & 1 & $5,80 \%$ \\
\hline If & G022 & Then & P17 & 0,4 & \multirow{2}{*}{1} & \multirow{2}{*}{$5,80 \%$} \\
\hline If & G030 & Then & P17 & 1 & & \\
\hline If & G022 & Then & $\mathrm{P} 20$ & 0,8 & 0,6 & $3,50 \%$ \\
\hline \multirow[t]{2}{*}{ If } & G030 & Then & P21 & 1 & 0,4 & $2,30 \%$ \\
\hline & \multicolumn{3}{|c|}{ Total CF seluruh Gejala } & 17,2 & & \\
\hline
\end{tabular}

Pada tampilan interface (tampilan antar muka) ini menampilkan informasi tentang bekam secara umum. Pada form ini disajikan menu untuk login. Ada dua username yang diberikan hak akses untuk masuk pada system ini, diantaranya: pakar dan user. Pakar menginput data sebagai basic knowledge pada sistem, sedangkan user melakukan penginputan data pasien hingga melakukan konsultasi diagnosa penyakit.

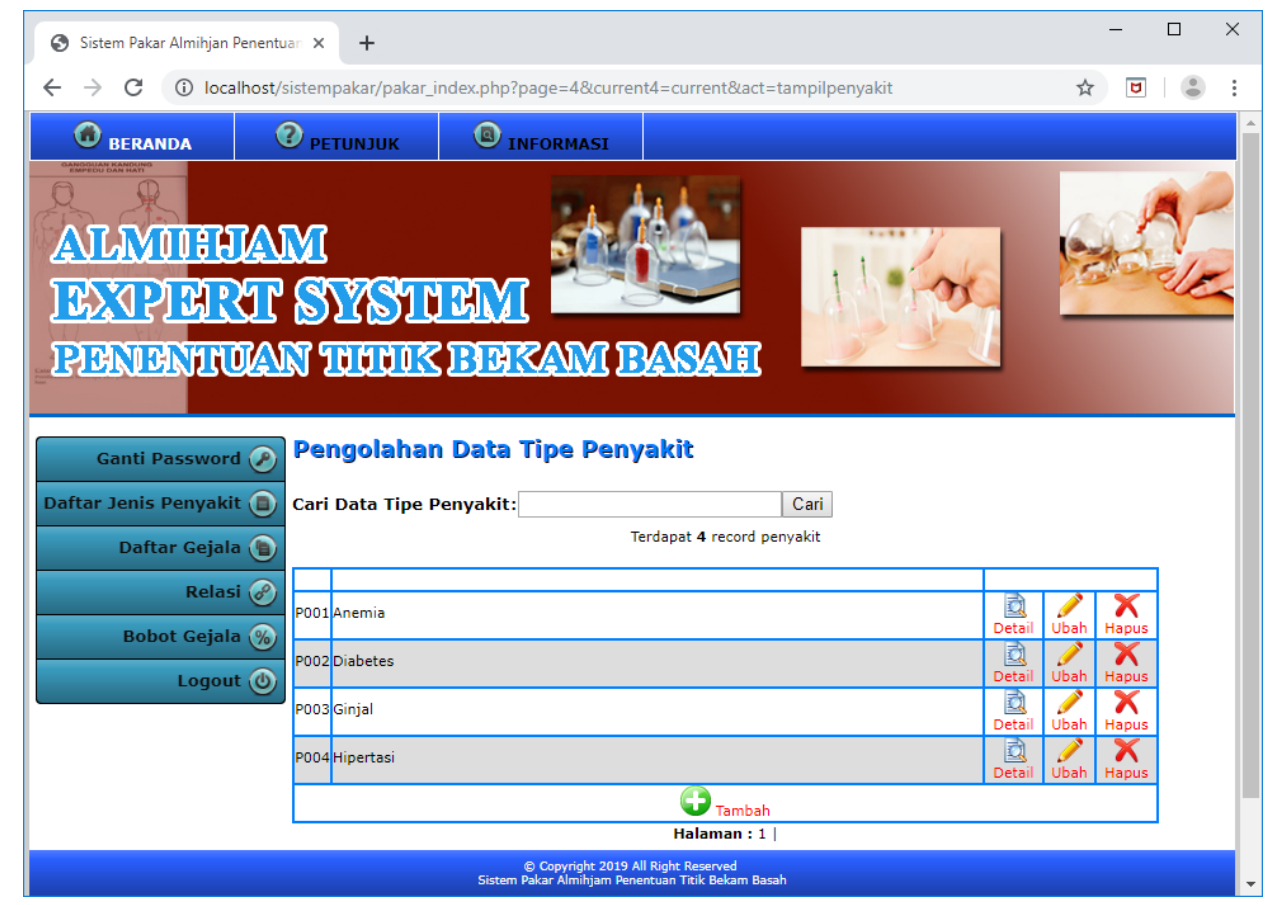

Gambar 2. Tampilan menu utama dan diagnosis penyakit 


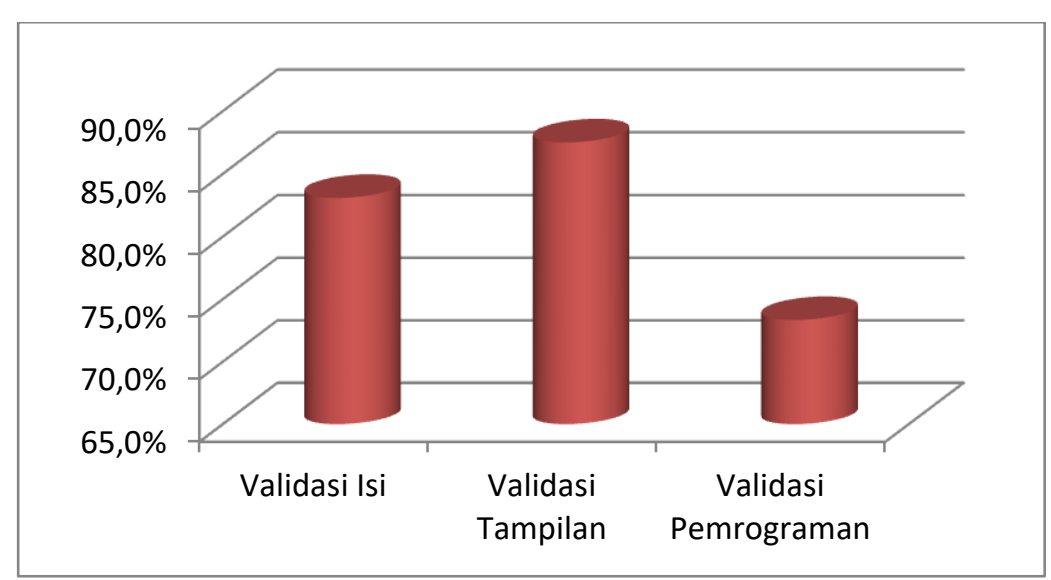

Gambar 3. Hasil Validasi dari tiga ahli

System yang diuji coba sudah melewati 3 tahap validasi oleh 3 orang ahli, diantaranya validasi pada sisi pemrograman, validasi pada sisi isi, dan validasi pada sisi tampilan. Berdasarkan hasil validasi dari tiga ahli maka dapat ditampilkan hasil kesimpulan seperti pada diagram dibawah ini:

\section{KESIMPULAN}

Berdasarkan hasil penelitian sebagaimana telah diuraikan dalam bab sebelumnya, maka dapat disimpulkan sebagai berikut: (1) Hasil dari penelitian ini menunjukkan bahwa sistem ini mampu membantu berbagai pihak khususnya asisten terapis dan pasien dalam memberikan diagnosa hasil penyakit yang lebih akurat. (2) Dengan menggunakan algoritma forward chaining yang digabungkan dengan algorima fuzzy menunjukkan hasil titik bekam basah yang lebih akurat.

\section{Daftar Pustaka}

Adrial, R. (2017). Aplikasi Sistem Pendukung Keputusan Stadium Penyakit Kanker Payudara Menggunakan Logika Fuzzy Berbasis Android. Jurnal Kesehatan Komunitas, 3.3, 117-122.

Akbar, N., \& Mahati, E. (2013). Pengaruh Bekam Basah terhadap Kolesterol dan Tekanan Darah pada Pasien Hipertensi di Semarang. Jurnal Kedokteran Diponegoro. Jurnal Kedokteran Diponegoro, 2(1).

Fitriati, I. (2015). Optimalisasi Solusi Interaktif Penyembuhan Islami Berdasarkan Diagnosa Tiga Indera Dengan Strategi Forward Chaining Menggunakan Algoritma Fuzzy. JURNAL PENDIDIKAN MIPA ISSN : 2088-0294, 59 - 71.

Fitriati, I., \& Ghazali, M. (2018). Pengembangan Media Pembelajaran Menggunakan Software Lecture Maker pada Mata Pelajaran Pemrograman Dasar di SMK Negeri 9 Bima. JURNAL PENDIDIKAN MIPA, 8.1, 77-86.

Hamdani, H. (2016). Sistem Pakar Untuk Diagnosa Penyakit Mata Pada Manusia. Informatika Mulawarman: Jurnal Ilmiah Ilmu Komputer, 5(2), 13-21.

Hayadi, B. H., \& Rukun, K. (2016). What is Expert System, ed 1. Yogyakarta: Deepublish Publisher.

Sutojo, T., Mulyanto, E., \& Suhartono, V. (2011). Kecerdasan Buatan. Andi Offset.

Umar, D. W. A. (2016). SEMBUH DENGAN SATU TITIK Cetakan XI. Solo: Pustaka AL-Qowam.

Yunus, M., \& Setyowibowo, S. (2011). Aplikasi Sistem Pendukung Keputusan Diagnosa Penyakit Paru-paru dengan Metode Forward Chaining. JURNAL TEKNOLOGI INFORMASI: Teori, Konsep, Dan Implementasi, 2(2), 95-114. 